\title{
THE REPRODUCTIVE STRATEGY OF Leporinus friderici (Characiformes, Anostomidae) IN THE PARANÁ RIVER BASIN: THE EFFECT OF RESERVOIRS
}

\author{
LOPES, C. de A., BENEDITO-CECILIO, E. and AGOSTINHO, A. A. \\ Universidade Estadual de Maringá, DBI, Núcleo de Pesquisas em Limnologia, \\ Ictiologia e Aqüicultura (NUPELIA) \\ Correspondence to: Célia de Almeida Lopes, Universidade Estadual de Maringá, NUPELIA, Av. Colombo, \\ 5790, Bloco H-90, CEP 87020-900, Maringá, PR, Brazil, e-mail: celia@ nupelia.uem.br \\ Received November 20, 1998 - Accepted January 7, 1999 - Distributed May 31, 2000
}

(With 7 figures)

\begin{abstract}
The reproductive strategy of a species depends upon the interaction between intrinsic and extrinsic factors. Examining the population of Leporinus friderici in two reservoirs of the Upper Paraná River basin in reference to first gonadal maturation and breeding season and sites, the present investigation tested whether the environment formed by damming promoted spatial and temporal changes in the reproductive strategy of this species. Analyses of sex ratios showed that females significantly predominated in Itaipu, while in Corumbá the sexes were about equal with a slight predominance of males. Size-associated sexual dimorphism was observed, that is females dominated the longer length categories, and males the shorter. The minimum size at which $L$. friderici initiated reproduction varied from year to year, and was larger in the periods soon after formation of both reservoirs. In Itaipu, stabilization between the maximum and minimum lengths at first maturation was also noted after year 6 following closure and continuing until year 15. In general, the breeding season lasted from October through April, although cyclic changes in the duration and intensity of this season were evident. Young individuals predominated during the entire study period in Corumbá. The formation of Itaipu Reservoir had a greater effect on the reproduction of $L$. friderici, where a gradual adaptation of the reproductive strategy of this species may possibly have been occurring. It is also possible that some of the characteristics of the Itaipu population will in the future be shown by the Corumbá population. It was concluded that reproductive strategies constitute ecological adaptations that are temporally and spatially altered and are fitted to resource availability and environmental pressure.
\end{abstract}

Key words: Paraná River basin, Leporinus friderici, reproduction, reservoir.

\section{RESUMO}

\section{Estratégia reprodutiva de Leporinus friderici (Characiformes, Anostomidae) na bacia do rio Paraná: efeito de represamentos}

A estratégia reprodutiva de uma espécie é dependente da interação entre fatores intrínsecos e extrínsecos. Examinando a população de Lelporinus friderici em dois reservatórios da bacia do alto Rio Paraná, com referência ao tamanho da primeira maturação gonadal, época e local de reprodução, o presente trabalho testa se o ambiente formado com o represamento promove alterações espaço-temporais na estratégia reprodutiva da espécie. Analisando a proporção sexual, as fêmeas predominaram, significativamente, em Itaipu, enquanto em Corumbá foi evidenciada igualdade sexual com leve predomínio de machos, sendo constatado, todavia, para a espécie em questão, dimorfismo sexual associado ao tamanho, isto é, fêmeas prevaleceram nos maiores comprimentos e machos nos menores. O tamanho mínimo em que a espécie inicia a reprodução variou anualmente, sendo maiores nos períodos logo após a formação de ambos os reservatórios. Em ltaipu, foi notada ainda estabilização entre os máximos e mínimos comprimentos de primeira maturação, após o sexto ano de represamento mantendo-se no décimo quinto ano. Em geral, o 
período reprodutivo estabelecido foi de outubro a abril, no entanto, alterações cíclicas na duração e intensidade deste período foram evidenciadas. Os indivíduos jovens predominaram durante todo o período de estudo em Corumbá. A formação do reservatório de Itaipu promoveu efeito maior sobre a reprodução de Leporinus friderici, onde possivelmente está ocorrendo um processo gradativo de adaptações da estratégia reprodutiva da espécie. É possível supor, ainda, que algumas das características exibidas pela população em ltaipu se manifestem futuramente naquela de Corumbá. Conclui-se, portanto, que as estratégias reprodutivas constituem-se em adaptações ecológicas, alteradas temporal e espacialmente e condicionadas à oferta de recursos e à pressão ambiental.

Palavras-chave: Bacia do Rio Paraná, Leporinus friderici, reproducão, reservatório.

\section{INTRODUCTION}

In aquatic environments, the expression of the reproductive strategy of a species depends on the interaction between intrinsic factors, such as the metabolism of the organisms themselves, and extrinsic factors resulting from existing environmental conditions, such as the quality of reproductive habitats and interspecific relationships, as well as physical factors and flood regimes (Nikolsky, 1963; Lowe-McConnel, 1987; Wootton, 1989).

Artificial environmental conditions caused by reservoir construction have led to habitat changes, with consequences for the composition and structure of fish populations (Agostinho et al., 1992). The reproductive success of a species is a limiting condition for its maintenance and exploitation in the new environment.

In this process, the balance between the advantages and disadvantages in the allocation of energy for reproductive strategy and its variations (tactics) is the factor determining the characteristics of the life history of an organism, such as age or size at sexual maturation, survival rate, fecundity, and reproductive frequency.

Some studies have demonstrated the plasticity of reproductive strategies in fishes confronted with the environmental conditions and pressures caused by reservoir formation (Ferreira \& Godinho, 1990; Agostinho et al., 1992; Shatunovskii et al., 1996). Knowledge of reproductive strategies is fundamental to implementation of management measures and preservation of the populations of native fishes, as well as contributing to knowledge of the species' ecology. Nevertheless, the changes in populations subjected to the unpredictable conditions of the first years of reservoir formation have rarely been documented. Information from such studies may also be useful in evaluating the evolutionary pattern and the ecological relationships which make it possible for a species to survive in these environments.

The present investigation examined the regularity of the reproductive strategy of the populations of Leporinus friderici in two reservoirs of the Upper Paraná River basin, with special reference to the size at first gonadal maturation, and the breeding season and sites. It tested whether the environment formed by damming the river promoted different local reproductive modes, and whether temporal changes in reproductive strategy are patterns for the species, or are dependent on the impacted environment.

\section{MATERIAL AND METHODS}

The Paraná River basin contains a series of reservoirs that were constructed gradually throughout its extent. Corumbá Reservoir, located on the upper stretch of the Paraná River, and the Itaipu Reservoir on the lower stretch of its middle course, have distinct characteristics. Itaipu Reservoir was closed in October 1982 and eventually attained an area of $1,460 \mathrm{Km}^{2}$ at its maximum level, with mean depth $21.5 \mathrm{~m}$ and maximum depth $170 \mathrm{~m}$. The residence time of the water is 40 days (Benedito-Cecilio, 1994). The more recently formed Corumbá Reservoir was closed in August 1996. Its area is $65 \mathrm{Km}^{2}$, mean depth $23 \mathrm{~m}$, and mean water residence time 30 days (De Filippo \& Soares, 1996).

In Corumbá, 12 sampling stations were established along the Corumbá River and its main tributaries, the Peixe, Sapé, and Pirapitinga Rivers. The Corumbá was divided into three subsystems: Tributaries (Trib; Stations 1-4), Reservoir (Rese; 
Stations 5-11), and Downstream (Jusa; Station 12). Collections were made monthly in both the preclosure (April-August 1996) and the post-closure (September 1996-August 1998) phases.

In Itaipu Reservoir, 21 sampling points were established, also grouped into subsystems: Rivers (Rios; Stations 1 and 2), Upstream (Mont; Stations 3-5); Reservoir (Rese; Stations 6-13); Tributaries (Trib; Stations 14-20), and Downstream (Jusa; Station 21). Collections were made monthly from November 1983 through October 1989, and trimonthly from March through December 1997. Samples were taken during the period before closure of the reservoir by Cetesb (Cetesb/Itaipu Binacional, 1979; Cetesb/Itaipu Binacional, 1981). Leporinus friderici was not recorded in Itaipu before the reservoir was closed.

Fishing gear consisted of stationary nets with mesh sizes 3 to $14 \mathrm{~cm}$, and trammel nets with mesh 6 to $9 \mathrm{~cm}$ between nonadjacent knots, set out for 24 hours at each sampling station. Standard length (Ls), total weight (Wt), and gonadal weight (Wg) were measured for each specimen caught. Specimens were sexed and the state of gonadal maturation was estimated by macroscopic inspection of the gonads (Vazzoler, 1996).

\section{Data analysis}

The sex ratio per standard length class, environment, and season was established. Significant differences from 1:1 were analyzed using the $\mathrm{G}$ test (Zar, 1974).

The mean size at first sexual maturation (Lpm) was considered the size at which $50 \%$ of the individuals begin the reproductive process (Vazzoler, 1996). This datum was calculated for each year of the study.

The relative contribution of gonadal weight to total weight, the Gonad-Somatic Relationship (GSR) of each individual was used to quantify the degree of gonadal maturation (Isaac-Nahum \& Vazzoler, 1987; Vazzoler et al., 1989). The highest values of this ratio were used as indicators of the breeding season. Breeding sites were identified as those with the largest concentration of individuals with mature and emptied gonads and the highest mean GSR values.

The well-being of the species was evaluated using monthly values for the condition factor $(K)$, obtained from the equation $\mathrm{K}=\mathrm{Wt} / \mathrm{Ls}^{\mathrm{b}}$, $\mathrm{b}$ being the angular coefficient of the ratio $\mathrm{Wt} / \mathrm{Ls}$. The relationships between breeding sites and seasons and the condition factor were evaluated by ANOVA. The effect of reproduction on the condition of the fish was evaluated by the regression between gonadal weight $(\mathrm{Wg})$ and the residues for the body weight ratio $(\mathrm{Wt}-\mathrm{Wg})$ and standard length (Ls).

The numerical abundance of young and adult fish was quantified as catch per unit effort (CPUE = $\mathrm{C} / \mathrm{E}^{*} 1000$, where $\mathrm{C}$ is the number of specimens caught and $\mathrm{E}$ is the effort, in $\mathrm{m}^{2}$ of net for 24 hours). Young specimens were considered as those with immature gonads, and adults those with gonads in later stages of maturation.

\section{RESULTS}

No common pattern was observed in the predominance of one sex between the environments of either reservoir. In Itaipu, females predominated significantly in the larger and more lotic environments, while in Corumbá males dominated in the lotic as well as lentic stretches sampled (Fig. 1A). Year to year, females were always more abundant in Itaipu, and dominated significantly during most of the study period. In Corumbá, no significant differences in sex ratios were observed during the study period, although males predominated (Fig. 1B). Both populations showed differences in the sex ratios in the shorter and longer length classes, females being longer than males (Fig. 1C).

The size at which $L$. friderici began reproductive activity $(\mathrm{Lpm})$ in the reservoirs varied from year to year, but was similar for both sexes. Lengths at first gonadal maturation in Corumbá were greater than those calculated for Itaipu (Figs. 2A and B). In both cases $\mathrm{Lpm}$ was greater during the first years after flooding, and then decreased. In Itaipu, following a gradual reduction in size, an increase and stabilization in mean length at first gonadal maturation were observed in the last three years studied (years 6, 7, and 15).

In both environments, the reproductive investment of the females was much higher than that of the males (Figs. 3A and B). In general, in Itaipu Reservoir the GSR between females and males was 3.74, while in Corumbá it was 2.58 . 


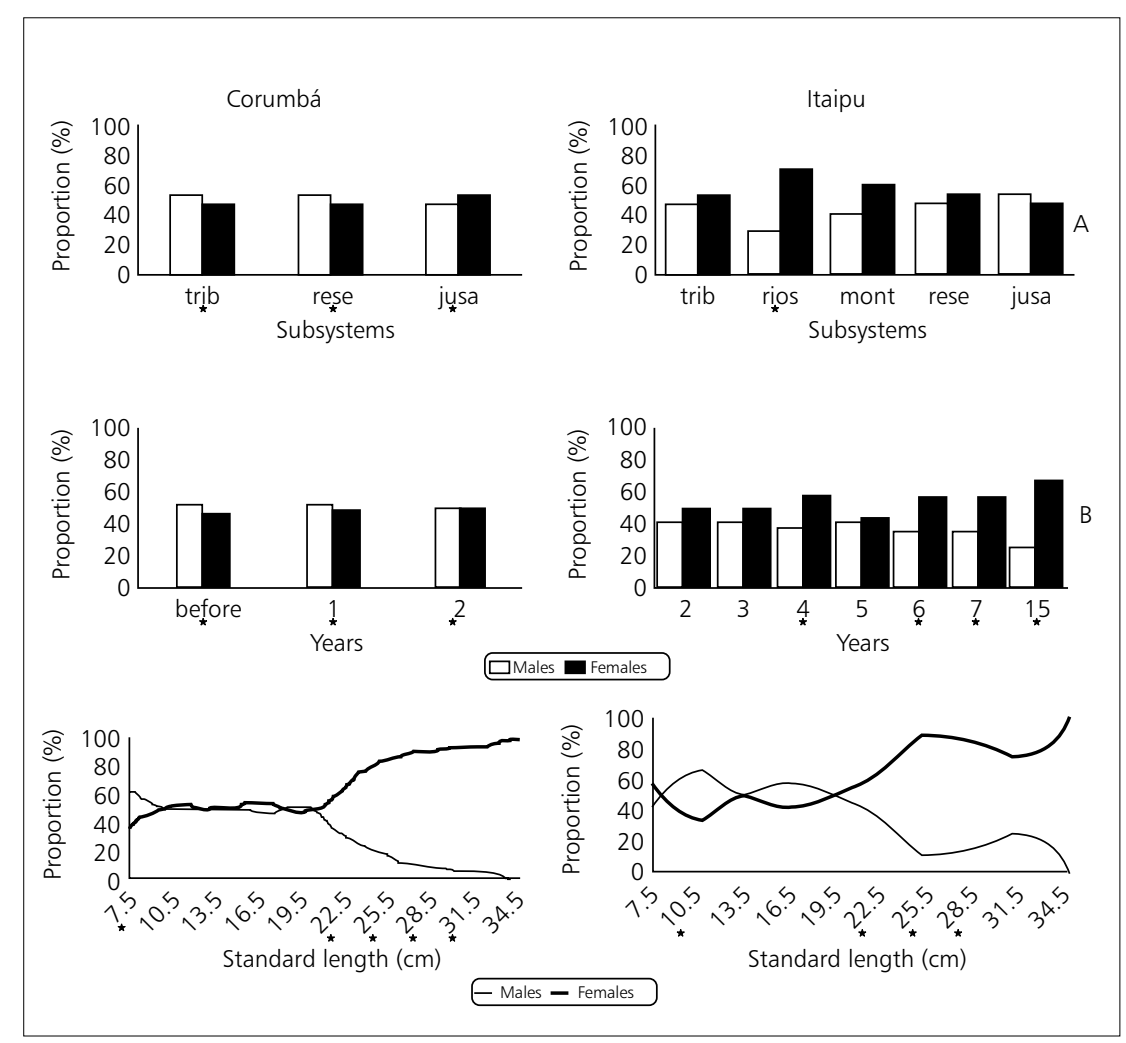

Fig. 1 - Sexual proportion of L. friderici for subsysistems. (A) periods (B) and class of standard length (C) (* significant at $5 \%$ ).

However it is important to note that soon after closure of Itaipu Reservoir, this ratio was very similar to that observed in Corumbá for the same stage of filling of the reservoir, and gradually increased over time.

The breeding season extended from September through April, although annual variation was seen in both reservoirs. The relationship between the duration of the breeding season and the reproductive intensity (values of mean GSR) was also notable: the greater the duration, the lower the values, while the shorter seasons were represented by higher values of the mean GSR (Figs. 3A and B).

The breeding sites selected by the populations of $L$. friderici in Corumbá and Itaipu corresponded to the largest and most lotic environments sampled (Figs. 4A and B).

The relationship between breeding sites and season and the well-being of the species, interpreted as the values of the condition factor
(K), was different in the two reservoirs (Figs. 5A and B). In Corumbá, the lower values of the condition factor were associated with sites (ANOVA: $\mathrm{df}=6 ; \mathrm{F}=4.890 ; \mathrm{p}<0.05$ ) and seasons (ANOVA: $\mathrm{df}=26 ; \mathrm{F}=24.845 ; \mathrm{p}<0.05$ ). In Itaipu, the condition of the species was quite variable and was unrelated to season (ANOVA: $\mathrm{df}=53 ; \mathrm{F}=$ $0.792 ; \mathrm{p}=0.858)$, although a relationship with sites was recorded (ANOVA: $\mathrm{df}=16 ; \mathrm{F}=14.911 ; \mathrm{p}<$ 0.05). In Corumbá, heavier gonads showed a constant and smaller residual variance of the standard length-body weight ratio, while for Itaipu the variances were random and independent of size (Figs. 6A and B). This showed that there was no pattern in utilization of stored energy by $L$. frideric $i$ in the reservoirs studied.

Catch per unit effort (CPUE) in Corumbá Reservoir was characterized by the high abundance and dominance of young fish in the population, mainly during the second year after closure (64.8 ind./1,000 $\mathrm{m}^{2}$ of net/24 hours). 


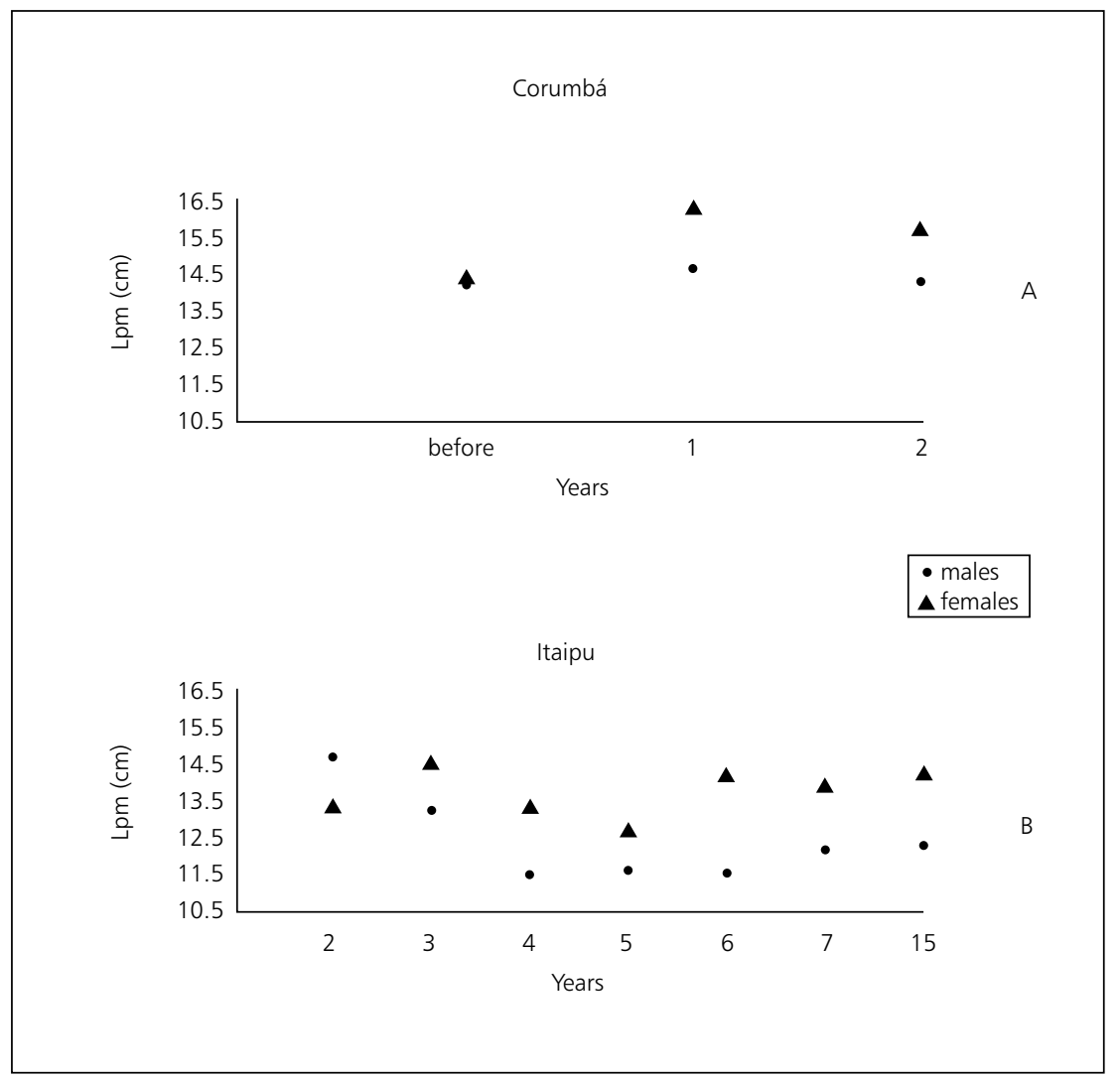

Fig. 2 - Mean size at first maturation (Lpm) of L. friderici for period.

Although adult individuals were abundant in Itaipu, the largest catches of young fish were recorded in year 3, 7, and 15 following reservoir formation (Figs. 7A and B), and the CPUE remained lower than 2.0 ind./1,000 $\mathrm{m}^{2}$ of net/24 hours.

\section{DISCUSSION}

Deviations from a 1:1 among males and females reflect responses of the species to existing conditions in the system. In many cases food supply is a determining factor, and females predominate when food is abundant, while males predominate in oligotrophic environments (Nikolsky, 1963). Food would influence the metabolism through hormonal activity, causing changes in the production of individuals of one sex.

The often statistically significant predominance of females in Itaipu and the equal proportion of sexes in Corumbá (with a slight predominance of males in the pre-closure period and the first year after closure) may be related to the trophic state of those environments, since Corumbá Reservoir is oligotrophic (UEM.Nupelia/ FURNAS, 1998) and Itaipu is mesotrophic (SUREHMA/Itaipu Binacional, 1989). Current velocity did not appear to affect aggregation of the sexes, since no significant pattern of predominance of either sex was observed in relation to type of environment (lentic or lotic).

Size-associated sexual dimorphism was observed in L. friderici, since females predominated in the longer length classes, and males in the shorter classes. This characteristic has also been noted for several other teleost species (Narahara et al., 1985; Kraak, 1996; Canan \& Gurgel, 1997). It is admitted that more or less preferential catch of specimens of one sex would reflect different growth rates (Munro, 1976), which may also be a consideration in the case of $L$. friderici. 


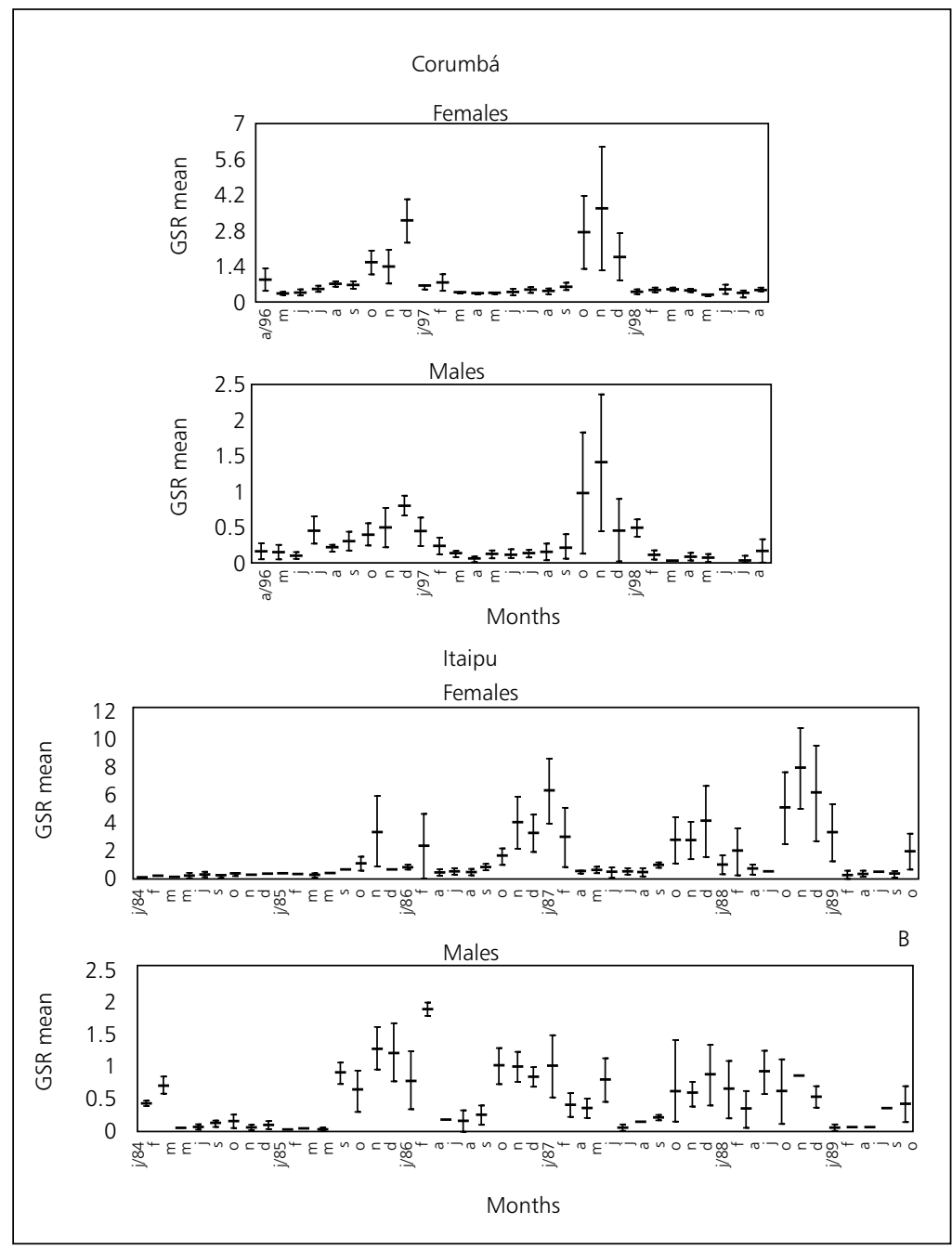

Fig. 3 - Means monthly values of the Gonad-Somatic Relationship (GSR) for males and females of L. friderici (horizontal line interns = mean GSR; vertical line = confindence interval).

The minimum size at first reproduction varied annually, and was larger in the periods immediately after formation of both reservoirs. Although there are no studies on the relationship of fecundity and standard length in L. friderici, in most fish species the highest growth rates translate into greater egg production, since fecundity appears to increase with body size of the individual (Schifino et al., 1998; Fialho et al., 1998). Thus the post-closure period may possibly be marked by greater fecundity of the species. On the other hand, the costs of fecundity influence directly or indirectly the availability of energy for future reproduction. The direct costs of fecundity would over the long term reduce the availability of stored energy used for reproduction, while the indirect costs would reduce growth rate, indirectly influencing future reproduction (Schwarzkopf, 1993). Decreases in mean length at first maturation of $L$. friderici were also observed immediately after the impact of the closure of Itaipu Reservoir. In Itaipu the maximum and minimum mean lengths at first maturation stabilized following year 6 after closure, and continued through year 15. Similar behavior can be expected in the Corumbá population if no other environmental disturbance occurs. 

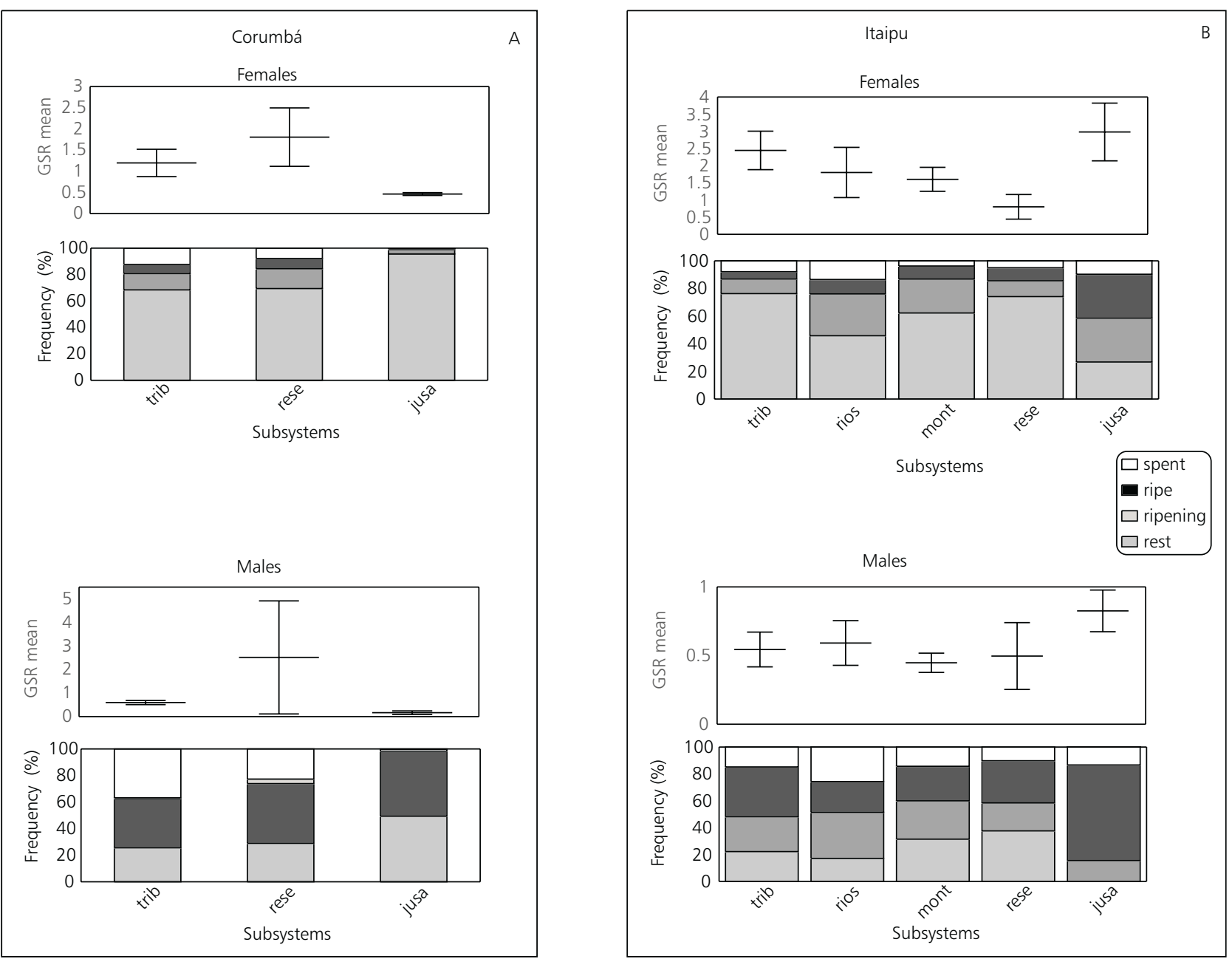

Fig. 4 - Means values of the Gonad-Somatic Relationship (GSR) and frequency of the state of maturation gonadal for males and females of $L$. friderici, in each subsystems of the reservoirs sampleds (horizontal line interns = mean GSR; vertical line = confindence interval). 




Fig. 5 - Means values of the condition factor $(\mathrm{K})$ of $L$. friderici, for month and subsysistems for each reservoir sampled (horizontal line interns $=$ mean $\mathrm{K}$; vertical line = confindence interval).

The breeding season established for $L$. friderici was generally from September through April. Nevertheless, cyclic changes in the duration and intensity of the breeding season were observed in Itaipu. Longer or shorter spawning seasons must favor the permanence of a species in reservoirs, since the virtual reproductive losses of a shorter season are compensated by success in the survival of the young in the same or the subsequent season. The continuity of stimuli for initiation and intensity of spawning are, therefore, a consequence of the annual variability of stored and environmental resources available to the individuals.
Biotic as well as abiotic factors are uncouplers of the reproductive process in the environments considered. However we can suppose that the evident cyclical changes in environmental conditions, such as temperature and rainfall, are related to the physiological rhythm of $L$. friderici and uncouple the reproductive process, as has been commonly observed by many investigators for other species (June, 1977; Fishelson et al., 1996; Mol, 1996). Relationships between the breeding season and sudden rise in river level, changes in current flow, water pressure, and occasionally chemical factors have been observed for $L$. friderici (Schubart, 1943; Nomura, 1975; Barbieri \& Garavello, 1981). 


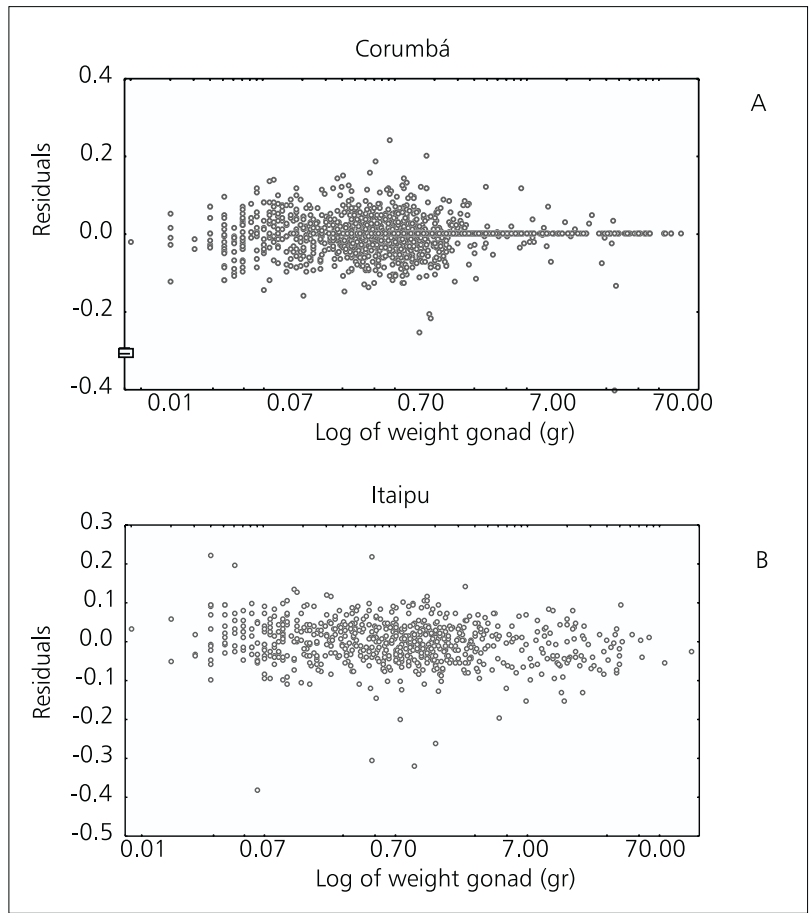

Fig. 6 - Relationship among the residues (Ls $x \mathrm{Wt}$ ) and $\log$ of the weight of the gonads of L. friderici.

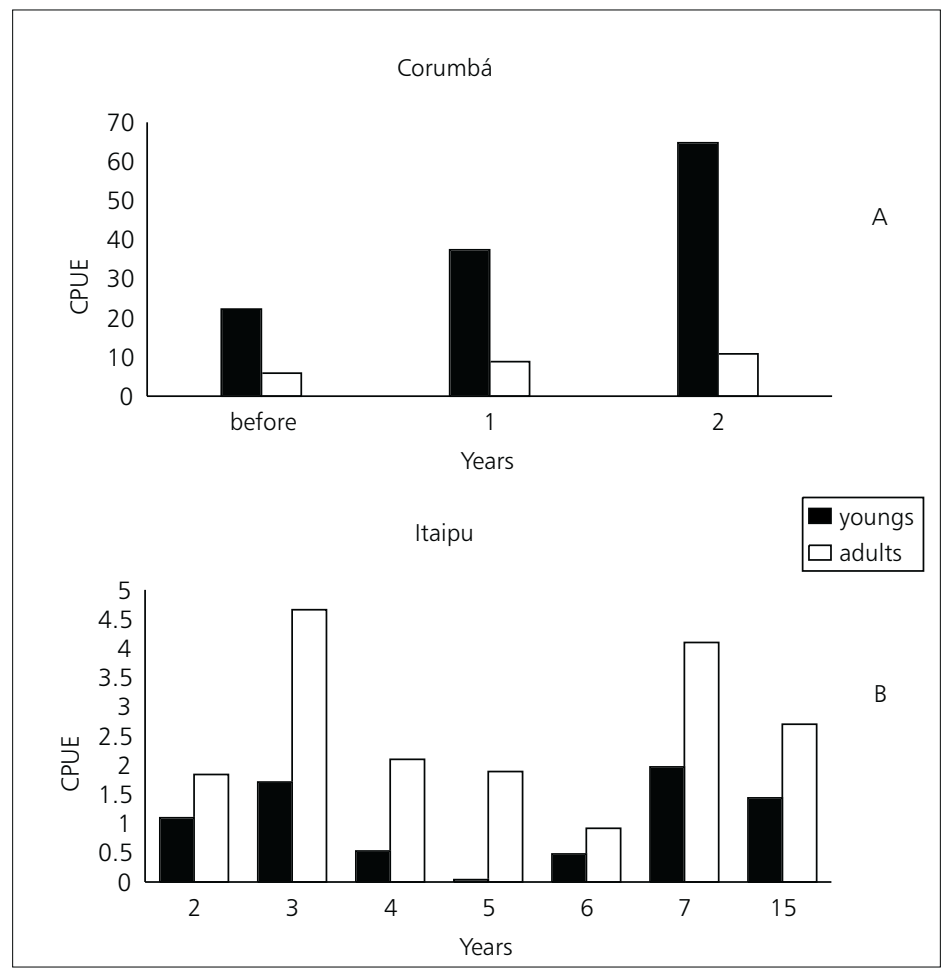

Fig. 7 - Captures for unit of effort (CPUE) of immature and adults of L. friderici. 
Information on the preferential spawning habitats of a species is fundamental, since it constitutes basic ecological data on life history and can be used as a management tool in environments impacted or regulated by man (Sempeski \& Gaudin, 1995). The habitats selected for spawning by $L$. friderici were similar in both reservoirs, corresponding to the largest and most lotic environments sampled. This tactic coincides with the migratory habit of the species (Nomura, 1976; FUEM/Itaipu Binacional, 1985). Nevertheless, Barbieri \& Santos (1988) recorded that $L$. friderici reproduces in Lobo Reservoir, an artificial environment only $8 \mathrm{Km}$ long and $900 \mathrm{~m}$ in mean width.

The requirements for spawning necessarily limit the spawning grounds of fish (Santos et al., 1996), which seek favorable conditions for development of their eggs, protection from predators, and reduction of environmental stresses (turbulence and oxygen deficit among others) (Potts, 1984). It is admitted that, of the reproductive tactics analyzed for $L$. friderici, the spawning grounds constitute the most specific reproductive requirement for this species in reservoirs, and current velocity is an important factor affecting selection of these environments.

The resources physiologically stored by $L$. friderici are directly related to its reproductive costs in Corumbá, since the lowest values of the condition factor were observed during the breeding seasons and at breeding sites. This condition has been commonly observed for other fish species (Santos et al., 1996; N'Da \& Déniel, 1993). Nevertheless, the same pattern could not be demonstrated in Itaipu, that is the variations in the physical condition of the species could not be attributed to changes in the breeding season, but coincided only with the spawning sites, possibly reflecting the availability of food in the environment. Interestingly, in Itaipu the fish appeared fatter than those caught in Corumbá, and gonadal weight was independent of body condition, which reinforces the above supposition.

The population of L. friderici in Corumbá consists basically of small individuals. This might be explained by three suppositions: i) there were sampling problems in locales where young fish were developing; ii) refuges were destroyed and consequently the fish were more vulnerable to catching; iii) this structure indicated the full population growth phase.

Other species were also sampled in the area of Corumbá Reservoir, including its river phase (UEM.Nupélia-FURNAS, 1997). In those catches there was no evidence of predominance of young fish, which does not support the first supposition. The second suggestion cannot be totally discarded, since fish species have specific tactics for spawning and development of the young and information about these behaviors is sparse, not only for $L$. friderici but also for most species of the Paraná River basin. However, the dominance of young fish was observed during the entire period of the study including the river phase, and was not shown to be an effect of reservoir formation. According to Odum (1986), a high proportion of young individuals provides evidence that a population is growing rapidly. This condition may reflect high recruitment in the region flooded by the Itumbiara Reservoir, just below the area studied. In spite of the fact that the present fish community there is dominated by species of lentic environments, lotic species such as the dourado, piapara, and piau are still caught by the commercial fishery of Itumbiara (Godinho, 1993).

In Itaipu, the higher incidence of young fish in year 2 (the period immediately after closure of the reservoir) may reflect the availability of food in that unstable colonization period, beside other determining factors such as predation and greater habitat availability.

The highest densities of young fish observed in year 7 appeared to have maintained themselves after 15 years following damming, and were similar to those observed for years 3 and 7. However, this fact is inconclusive since the abiotic and biotic conditions responsible for the recruitment process were not investigated, and could as well result from a cyclic environmental process.

In sum, it can be admitted that reproductive strategies are more ecological adaptations than genetic phenomena. These strategies undergo temporal and spatial changes, and are conditioned by resource availability and environmental pressure. The characteristics required for the spawning sites, nevertheless, are among the more limiting and specific reproductive tactics of $L$. friderici in reservoirs. 
Acknowledgments - We thank to Nupelia (Center for Research in Limnology, Ichthyology and Aquaculture) for infrastructural support, to Maria Salete Ribelatto Arita for revising the references, to Carolina Viviana Minte-Vera and Dr. Fábio Amôdeo Lansac-Tôha for the help ful comments to the manuscript and Janet W. Reid for the translate the text into English.

\section{REFERENCES}

AGOstinho, A. A., JUlio JR., F., BORGHETti, J. R. \& DOMANINSKI, J. R., 1992, Considerações sobre os impactos dos represamentos na ictiofauna e medidas para sua atenuação. Um estudo de caso: Reservatório de Itaipu. Rev. Unimar, Maringá, 14(supl): 89-107.

BARBIERI, G. \& GARAVELLO, J. C., 1981, Sobre a dinâmica da reprodução e da nutrição de Leporinus friderici (Bloch, 1794) na represa do Lobo, Brotas, SP (Pisces, Anostomidae). In: Anais do III Seminário Regional de Ecologia, São Carlos, UFSCar, pp. 347 367.

BARBIERI, G. \& SANTOS, E. P., 1988, Análise do crescimento e de aspectos reprodutivos da piava Leporinus friderici (Bloch, 1794) (Osteichthyes, Anostomidae) da represa do Lobo e do rio Mogi-Guaçu, SP. Ciênc. e Cult., 40(7): 693-697.

BENEDITO-CECILIO, E., 1994, Dominância, Uso do Ambiente e Associações Interespecíficas na Ictiofauna do Reservatório de Itaipu e Alterações Decorrentes do Represamento. Tese de Doutorado em Ecologia e Recursos Naturais, Universidade Federal de São Carlos, São Carlos, 173p.

CANAN, B. \& GURGEL, H. C. B., 1997, Estrutura populacional de Metynnis roosevelti Eigenmann, 1915 (Characidae, Myleinae) da Lagoa do Jiqui, Parnamirim. Rio Grande do Norte. Rev. Unimar, Maringá, 19(2): 479-491.

CETESB/ITAIPU BINACIONAL, 1979, Itaipu Binacional - Ictiofauna, São Paulo, 126p. (Relatório anual).

CETESB/ITAIPU BINACIONAL, 1981, Ictiofauna. Complementação do Invetário Ictiofaunístico. v. 3 (Relatório anual).

DE FILIPPO, R. \& SOARES, C. B. P., 1996, Caracterização Limnológica e da Qualidade da Água do Rio Corumbá e de seus Principais Afluentes na Área de Influência da UHE Corumbá. FURNAS - Centrais Elétricas S.A., Departamento de Meio Ambiente, Rio de Janeiro, 21p. (Relatório).

FERREIRA, R. M. A. \& GODINHO, H. P., 1990, Reproductive biology of the white-piau, Schizodon knerii (Steindachner, 1875) (Anostomidae) from reservoir in Southeast Brazil. Eur. Arch. Biol., 101: 331-344.

FIALHO, C. B., SCHIFINO, L. C. \& VERANI, J. R., 1998, Biologia reprodutiva de Oligosarcus jenynsii (Characiformes, Characidae) da Lagoa das Custódias, Tramandaí, Rio Grande do Sul, Brasil. Rev. Brasil. Zool., 15(3): 775-782.
FISHELSON, L., GOREN, M., VUREN, J. V. \& MANELIS, R., 1996, Some aspects of the reproductive biology of Barbus spp., Capoeta damascina and their hybrids (Cyprinidae, Teleostei) in Israel. Hydrobiologia, 317: 79-88

FUEM/ITAIPU BINACIONAL, 1985, Ecologia de Populações de Peixes no Reservatório de Itaipu, nos Primeiros Anos de sua Formação - $3^{a}$ etapa. Maringá, v. 3 (Relatório nov./83-fev./85).

GODINHO, A. L., 1993, E os peixes de Minas em 2010 ? Ciênc. Hoje, 16(9): 44-49.

ISAAC-NAHUM, V. I. \& VAZZOLER, A. E A. de M., 1987, Biologia reprodutiva de Micropogonias furnieri (Desmarest, 1823) (Teleostei, Sciaenidae) 2. Relação gônado-somática, comprimento e peso dos ovários como indicadores do período de desova. Bol. Inst. Oceanogr., SP, 35(2): 123-134.

JUNE, F. C., 1977, Reproductive patterns in seventeen species of warmwater fishes in a Missouri river reservoir. Env. Biol. Fish., 2(3): 285-296.

KRAAK, S. B. M., 1996, A quantitative description of the reproductive biology of the Mediterranean blenny Aidablennius sphynx (Teleostei, Blenniidae) in its natural habitat. Env. Biol. Fish., 46: 329-342.

LOWE-McCONNEL, R. H., 1987, Ecologycal Studies in Tropical Fish Communities. Cambridge University Press, 382p.

MOL, J. H., 1996, Reproductive seasonality and nest-site differentiation in three closely related armoured catfishes (Siluriformes: Callichthyidae). Env. Biol. Fish., 45: $363-381$.

MUNRO, J. J., 1976, Aspects of the biology and ecology of Caribbean reef fishes: Mullidae (goat-fishes). J. Fish. Biol., 9: 79-97.

N.DA. K. \& DÉNIEL, C., 1993, Sexual cycle and seasonal changes in the ovary of the red mullet, Mullus surmuletus, from the southern coast of Brittany. $J$. Fish Biol., 43: 229-244.

NARAHARA, M. Y., GODINHO, H. M. \& ROMAGOSA, E., 1985, Estrutura da população de Rhamidia hilarii (Valenciennes, 1840) (Osteichthyes, Siluriformes, Pimelodidae). Bol. Inst. Pesca, 12(3): 123-137.

NIKOLSKY, G. V., 1963, The Ecology of Fishes. 6" ed. Academic Press, London, 353p.

NOMURA, H., 1975, Marcação e migração da piava, $L e$ porinus copelandii Steindachner, (Osteichthyes, Anostomidae) do rio Mogi-Guaçu. Rev. Ceres, 22(123): 332-400.

NOMURA, H., 1976, Maturação sexual e índice gônadosomático da piava Leporinus copelandii Steindachner, 1875 do rio Mogi-Guaçu, SP (Osteichthyes, Anostomidae). Rev. Brasil. Biol., 36(2): 289-295.

ODUM, E. P., 1986, Ecologia. Editora Guanabara, Rio de Janeiro, 434p. 
POTTS, G. W., 1984, Parental behaviour in temperate marine teleosts with special reference to the development of nest structures. In: G. W. Potts \& R. J. Wootton (eds.), Fish Reproduction: Strategies and Tactics, Academic Press, London, 410p.

SANTOS, R. S., HAWKINS, S. J. \& NASH, R. D. M., 1996, Reproductive phenology of the Azorean rock pool blenny a fish with alternative mating tactics. $J$. Fish. Biol., 48: 842-858.

SCHIFINO, L. C., FIALHO, C. B. \& VERANI, J. R., 1998, Reproductive aspects of Cyphocharax voga (Hensel) from Custódias lagoon, Rio Grande do Sul, Brazil (Characiformes, Curimatidae). Rev. Brasil. Zool., 15(3): 767-773.

SCHUBART, O., 1943, A pesca na cachoeira de Emas do rio Mogi-Guaçu durante a piracema de 1942-43. Rev. Ind. Anim., 6(4): 93-16.

SCHWARZKOPF, L., 1993, Cost of reproduction in water skinks. Ecology., 74(7): 1970-1981.

SEMPESKI, P. \& GAUDIN, P., 1995, Habitat selection by grayling-I. Spawning habitats. J. Fish. Biol., 47: 256265.

SHATUNOVSKII, M. I., AKIMOVA, N. V. \& RUBAN, G. I., 1996, Response of reproductive systems of fishes to anthropogenic impacts. J. of Ikhtiol., 36(3): 247256.
SURHEMA/ITAIPU BINACIONAL, 1989, Estudos Limnológicos do Reservatório de Itaipu, Paraná, Brasil, no período de julho/87 a junho/88. Superintendência de Recursos Hídricos e Meio Ambiente, Curitiba, 104p.

UEM.NUPELIA/FURNAS, 1997, Estudos Ictiológicos na Área de Influência do AHE Corumbá. Fase rio. Maringá, 289p. (Relatório parcial mar-ago./96).

UEM.NUPELIA/FURNAS, 1998, Estudos Limnológicos na Área de Influência do Reservatório de Corumbá (GO). Maringá, 279p. (Relatório jul./96-nov./97).

VAZZOLER, A. E. A. de M., 1996, Biologia da Reprodução de Peixes Teleósteos: Teoria e Prática. EDUEM, Maringá, São Paulo, SBI, 169p.

VAZZOLER, A. E. A. de M., AMADIO, S. A. \& CARACIOLO-MALTA, M. C., 1989, Aspectos biológicos de peixes amazônicos. XII. Indicadores qualitativos do período de desova das espécies do gênero Semaprochilodus (Characiformes, Prochilodontidae) do baixo rio Negro. Rev. Brasil. Biol., 49(1): 175-181.

WOOTTON, R. J., 1989, Introduction: strategies and tactics in fish reproduction. In: G. W. Potts \& M. N. Wootton (eds.), Fish Reproduction: Strategies and Tactics. Academic Press, London, 410p.

ZAR, J. H., 1974, Biostatistical Analysis. Prentice-Hall, Inc., New Jersey, 620p. 